\title{
NEW LOCALITIES OF ADIANTUM CAPILLUS-VENERIS IN THE \\ RIVER-BASIN OF VOLARJA/VOLARNIK (THE JULIAN ALPS) \\ AND PHYTOSOCIOLOGICAL ANALYSIS OF ITS SITES NOVA NAHAJALIŠČA VRSTE ADIANTUM CAPILLUS-VENERIS V POREČJU VOLARJE/VOLARNIKA (JULIJSKE ALPE) IN FITOCENOLOŠKA ANALIZA NJENIH RASTIŠČ
}

\author{
Igor DAKSKOBLER ${ }^{1}$, Andrej MARTINČIČ ${ }^{2}$ \& Daniel ROJŠEK ${ }^{3}$
}

\begin{abstract}
New localities of Adiantum capillus-veneris in the river basin of the Volarja/Volarnik (the Julian Alps) and a phytosociological analysis of its sites

The article describes the localities, sites and communities of Adiantum capillus-veneris along the Volarja/Volarnik, the right tributary of the Soča River between Tolmin and Kobarid (9747/4). We classified its communities from three locations at elevations between 210 and $250 \mathrm{~m}$ into the subassociation Eucladio-Adiantetum cratoneuretosum commutati, a new variant Eucladio-Adiantetum hymenostylietosum recurvirostri var. Pinguicula alpina and into the new association Adianto-Molinietum arundinaceae.
\end{abstract}

Key words: phytosociology, synsystematics, Eucladio-Adiantetum, Adianto-Molinietum arundinaceae, Natura 2000, Upper Soča Valley, Julian Alps, Slovenia http://dx.doi.org/10.3986/fbg0019

\section{IZVLEČEK}

Nova nahajališča vrste Adiantum capillus-veneris $\mathrm{v}$ porečju Volarje/Volarnika (Julijske Alpe) in fitocenološka analiza njenih rastišč

$\mathrm{V}$ članku opisujemo nahajališča, rastišča in združbe vrste Adiantum capillus-veneris ob Volarji/Volarniku, desnem pritoku Soče med Tolminom in Kobaridom (9747/4). Njene združbe na treh krajih, na nadmorski višini od $210 \mathrm{~m}$ do 250 m, uvrščamo v subasociacijo Eucladio-Adiantetum cratoneuretosum commutati, v novo varianto Eucladio-Adiantetum hymenostylietosum recurvirostri var. Pinguicula alpina in v novo asociacijo Adianto-Molinietum arundinaceae.

Ključne besede: fitocenologija, sinsistematika, Eucladio-Adiantetum, Adianto-Molinietum arundinaceae, Natura 2000, Zgornje Posočje, Julijske Alpe, Slovenija

\footnotetext{
${ }^{1}$ Institute of Biology, Scientific Research Centre of the Slovenian Academy of Sciences and Arts, Regional unit Tolmin, Brunov drevored 13, SI-5220 Tolmin, and Biotechnical Faculty of the University in Ljubljana, Department of Forestry and Renewable Forest Resources, Večna pot 83, SI-1000 Ljubljana, igor.dakskobler@zrc-sazu.si

2 Zaloška 78 a, SI-1000 Ljubljana, andrej.martincic@siol.net

3 The Institute of the Republic of Slovenia for Nature Conservation, Regional Unit Nova Gorica, Delpinova 16, SI-5000 Nova Gorica,dar@zrsvn.si
} 


\section{INTRODUCTION}

The Mediterranean (subtropical, paleotemperate) fern Adiantum capillus-veneris, a character species of communities growing on permanently moist to wet rocks, is distributed in the hill belt across the entire southern stretch of the Alps (Aeschimann et al. 2004: 66). Two localities have been reported so far for the Alpine part of Slovenia, in the Brezna/Brizna Grapa gorge at the foothills of Mali Vrh above Grahovo ob Bači and in the river beds of the Mrzlica/Mrzli Potok brook under the village of Krn (at the elevation of $510 \mathrm{~m}$, which makes it its highest locality in Slovenia). Both localities have recently been described by RojšEK (2015a). We examined them in terms of phytosociology as well and looked also into the localities of this fern in the Soča Valley between Ročinj and Solkan, in the Idrija Valley, in the Karst region (Škocjan Caves) and on several other localities in Istria (DAKSKOBleR, MARTINČIČ \& RoJŠEK 2014). On 24 July 2016 we discovered new localities of this fern on three spots on the right bank of the Volarja/Volarnik at the village of Selišče (DAкsкoBLER 2017 and Figures 1 and 2). They are situated in the basin of the same river (the Volarja) as the locality in the Mrzlica gorge, but are much more extensive and occupy a different quadrant of Central-European flora mapping (9747/4). In this article we provide a detailed description of these localities and present the species composition of the studied communities with a phytosociological table. Based on our comparison with relevés from other regions of Slovenia we will classify these communities into the syntaxonomic system.

\section{METHODS}

Vegetation on the localities of Adiantum capillus-veneris was researched applying the standard Central-European method (BRAun-Blanquet 1964). On 12 re- corded plots we collected mosses and liverworts which one of the authors, Andrej Martinčič, determined in the laboratory. All relevés were entered into the

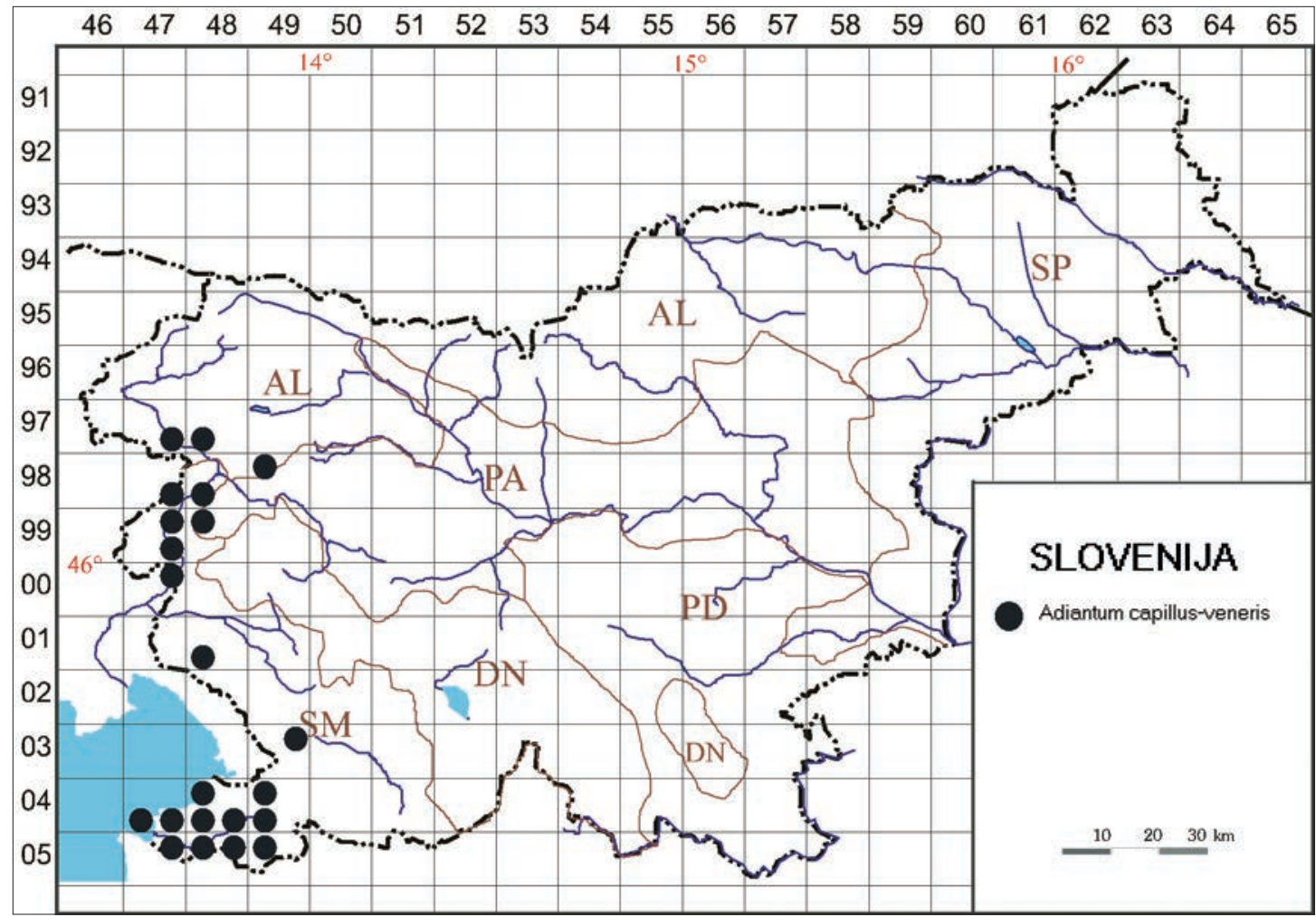

Figure 1: Distribution of Adiantum capillus-veneris in Slovenia Slika 1: Razširjenost vrste Adiantum capillus-veneris v Sloveniji 
FloVegSi database (T. SElišKar, VReš \& A. SELIŠKar 2003). Combined cover-abundance values were transformed into numerical values 1-9 (van der MAAREL 1979). Programme package SYN-TAX (PoDAni 2001) was used in numerical comparisons. The relevés were mutually compared by means of hierarchical classification. We applied the (unweighted) pair group method with arithmetic mean (UPGMA) and Wishart's similarity ratio as a measure of dissimilarity. The nomenclature source for the names of vascular plants is the Mala flora Slovenije (MARTINČIč et al. 2007). Ros et al. (2007) is the nomenclature source for the names of liverworts (Marcanthiophyta) and Ros et al. (2013) for the names of mosses. The nomenclature sources for the names of syntaxa are THEURILlAT (2004), ŠILC \& ČARNi (2012) and DAKSKOBLER, MARTINČIČ \& RoJŠEK (2014). The source for geological bedrock data was BusEr (1986, 1987, 2009), and ZUPANČIČ $(1995,1998)$, Mekinda-Majaron (1995) and Cegnar (1998) for climatic data.

\section{RESULTS AND DISCUSSION}

\subsection{Description of new localities of Adiantum capillus-veneris in the gorge of the Volarja}

The Volarja/Volarnik is the right tributary of the Soča River that originates from several distributaries on the southern slopes of the Krn Mountains and runs into the Soča at Selišče. In the lower course, for about 1.6 $\mathrm{km}$ between the confluence with the Soča and the confluence with the left tributary Mrzlica/Mrzli Potok/ Mrzuc/Zalazčenca, it has a relatively wide bed, whereas the beds above this section are narrow as they had been cut into troughs and ravines. The right (western)

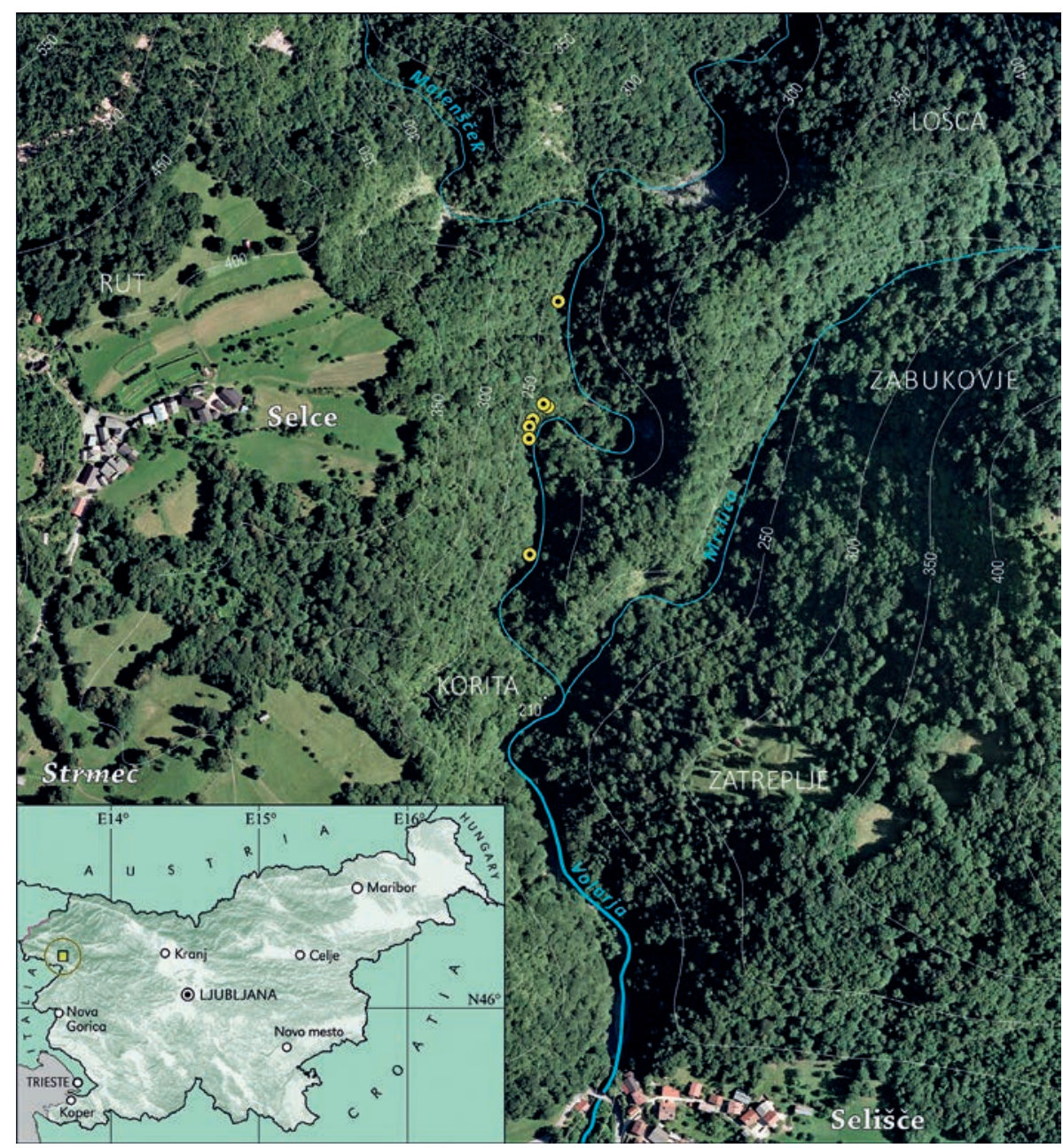

Figure 2: New localities of Adiantum capillus-veneris in the gorge of the Volarja near the village of Selišče Slika 2: Nova nahajališča vrste Adiantum capillus-veneris $v$ grapi Volarje pri vasi Selišče 
branch of the Volarja, in the terms used by PoDobnik (1983), has the same name, Volarja, even though it is marked as Malenšček on some of the older maps. This is also the name of the next right (western) tributary that joins the Volarja about $500 \mathrm{~m}$ upstream from the confluence with the Mrzlica. Its lower course as well as the section of the Volarja up until the confluence with the Mrzlica is known also as Brinta (MedveščeK \& SKRT 2016: 34). The Volarja/Volarnik has a distinctly torrential outflow and in autumn and spring, when the river bed is full of water, it looks like a small river in its lower course, but turns into a brook with little water in summer and spring. All of the new maidenhair fern localities are on the right bank along the sources in the relatively short section of the Volarja/Volarnik river bed (spanning about $500 \mathrm{~m}$ ) above the confluence with the Mrzlica, at elevations between 210 and $250 \mathrm{~m}$ (Figure 2). Heavily fractured and folded rock is formed by reddish platy limestone and marlstone interlayered with chert sheets and nodules $(\mathrm{K} 21+2$, Cenomanian and Turonian, between 90 and 105 million years old). The climate in this part of the Soča Valley is relatively warm and humid, with mean annual temperature be- tween 8 and $10^{\circ} \mathrm{C}$ and mean annual precipitation volume exceeding $2000 \mathrm{~mm}$.

The first maidenhair fern locality (relevé 14 in Table 1) is situated about $100 \mathrm{~m}$ above the confluence with the Mrzlica at the elevation of about $210 \mathrm{~m}$. More than one hundred maidenhair ferns grow here (a little more than $2 \mathrm{~m}$ high and $1.5 \mathrm{~m}$ wide) in tufa deposited by the seeping water in the lower part of a perpendicular and rather heavily overgrown, more than $10 \mathrm{~m}$ high rock level with distinct, heavily folded and fractured layers of limestone with intercalated marlstone (Figures 2 and 3).

The next locality is situated about $150 \mathrm{~m}$ upstream from the first, in a pronounced bend (Figures 2 and 4). The almost perpendicular right bank (slope break) is almost 80 metres high there and overgrown with open scrub communities. It is dominated by Salix appendiculata, Ostrya carpinifolia, Ulmus glabra and Fraxinus ornus, and by Molinia caerulea subsp. arundinacea, Calamagrostis varia and Erica carnea in the herb layer. Tufa is deposited from the seeping water. It is overgrown with maidenhair ferns that occur also on the moist parts of the parent material. The total surface

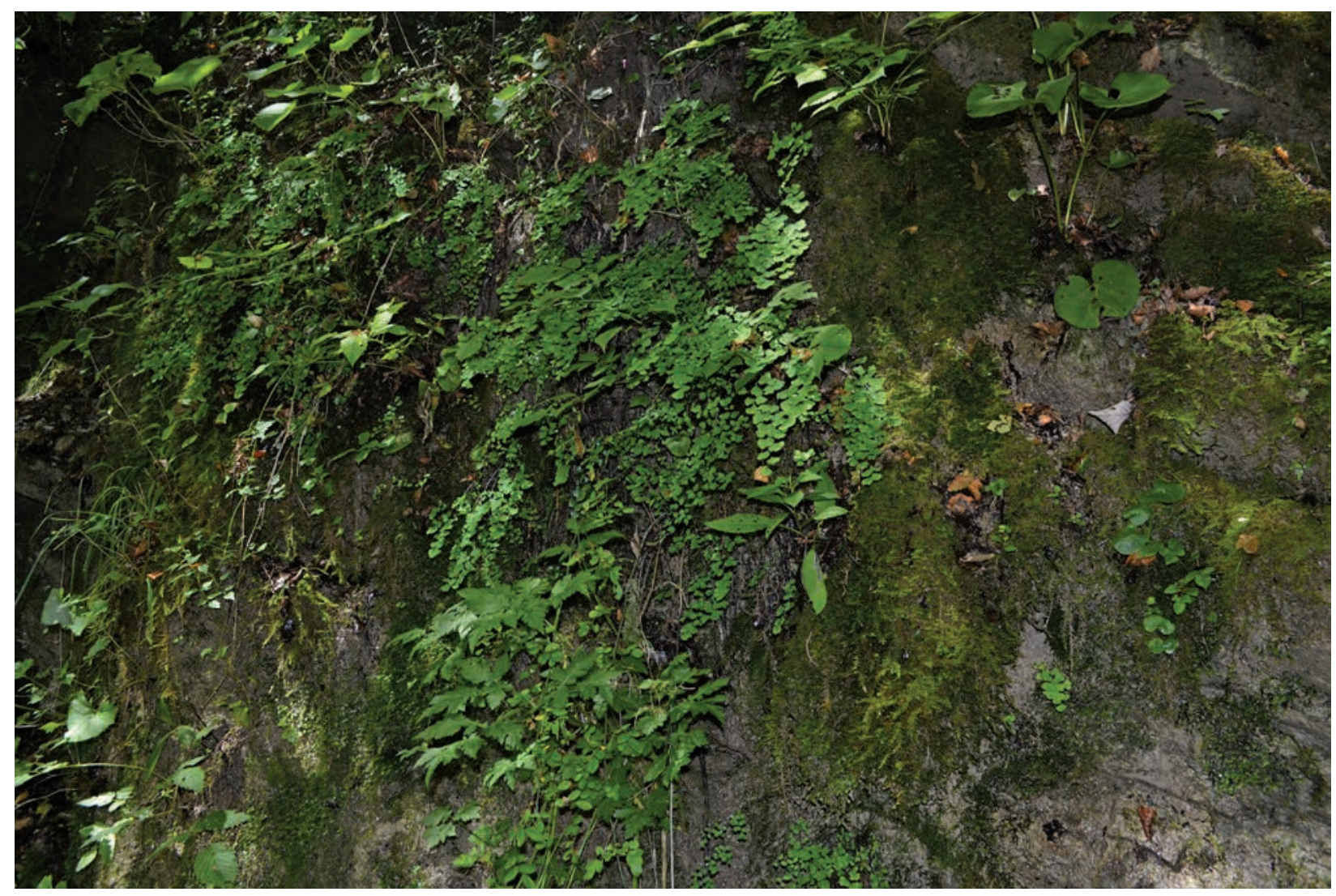

Figure 3: The first locality of Adiantum capillus-veneris in the gorge of the Volarja. Photo: I. Dakskobler Slika 3: Prvo nahajališče vrste Adiantum capillus-veneris v grapi Volarje. Foto: I. Dakskobler 


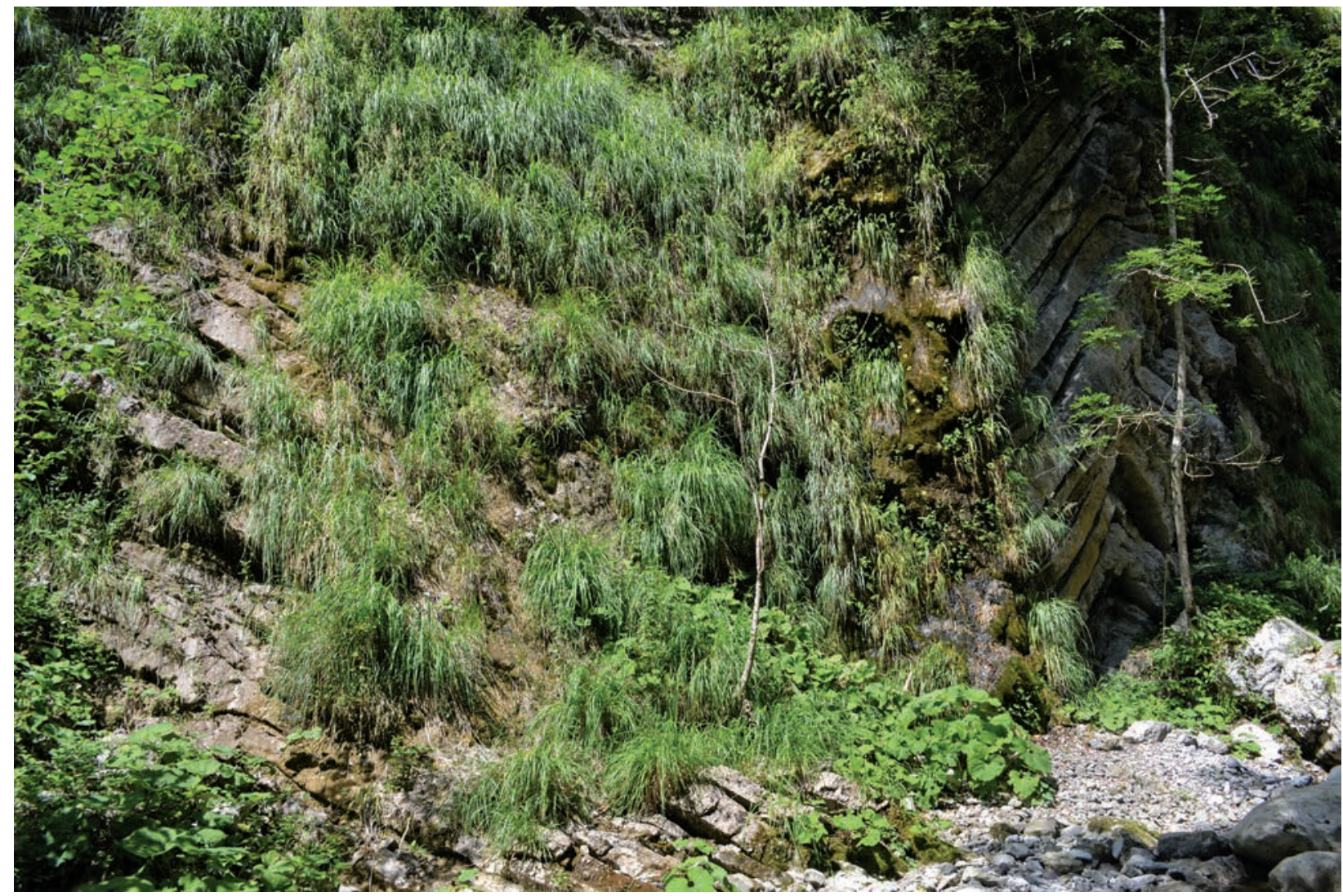

Figure 4: The second locality of Adiantum capillus-veneris in the gorge of the Volarja. Photo: I. Dakskobler Slika 4: Drugo nahajališče vrste Adiantum capillus-veneris v grapi Volarje. Foto: I. Dakskobler

area extends over several ares at between 220 a d $250 \mathrm{~m}$ a.s.l. It is estimated to comprise several thousand specimens of Adiantum capillus-veneris and is therefore its most prolific locality both in the Soča Valley and Slovenia. It is divided into two parts, the south and the north, by a 15-m-high and up to 7-m-wide, dry pillar of bare rock. The pillar is composed of striking limestone folds with marlstone intercalations. Five of our relevés (relevés 10, 11, 12, 13 and 20 in Table 1) were made on this locality.

The third locality is about $200 \mathrm{~m}$ above the second, at the elevation of ca. $235 \mathrm{~m}$. While the bank here is also perpendicular it is not as high as on the previous localities as it ascends only about four metres above the stream. Water seeping through the bedrock forms tufa deposits. These and marlstone layers are overgrown with maidenhair fern, a total of 20 plants. This is a modest yet striking locality, with vertical limestone and marlstone layers that are overgrown with mosses and maidenhair ferns (relevé 15 in Table 1).

\subsection{Phytosociological analysis of relevés with Adiantum capillus-veneris in the gorge of the Volarja}

Our comparison was based on 39 previously published relevés (DAKsKobler, Martinčič \& RojšEK 2014) to which we added seven relevés from the gorge of the Volarja and three relevés from the Sopet gorge at Plave (RojšEK, 2015b). The new table comprises also the relevé from the small brecciated spring above the Brezna/ Brizna gorge at Grahovo ob Bači (det. I. Dakskobler and D. Rojšek, 9. 12. 2014, relevé 19 in Table 1, mosses determined by A. Martinčič, 20. 2. 2017) and a relevé from the Piševec gorge (Šmarje pri Kopru, 0548/1, det. I. Dakskobler and Z. Sadar, 7. 5. 2014, mosses determined by A. Martinčič, 20. 2. 2017, relevé 18 in Table 1). A total of 51 relevés clustered into several groups that mainly correspond to the syntaxa we described in 2014 (Figure 6): Eucladio-Adiantetum eucladietosum,-hymenostylietosum recurvirostri, -cratoneuretosum commutati,-conocephaletosum conici and Phyteumato columnae-Adiantetum capilli-veneris. New relevés 


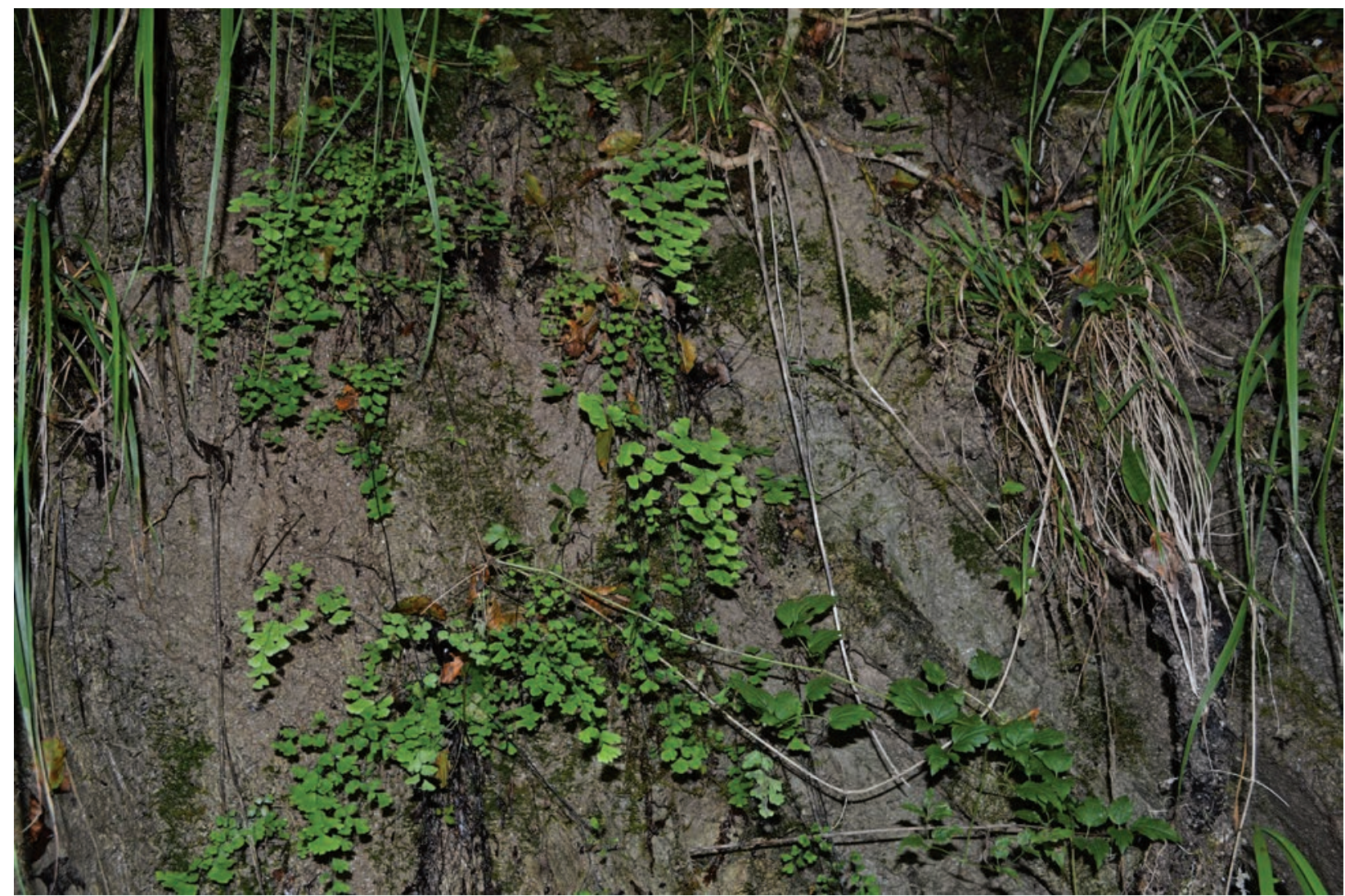

Figure 5: The third locality of Adiantum capillus-veneris in the gorge of the Volarja. Photo: I. Dakskobler Slika 5: Tretje nahajališče vrste Adiantum capillus-veneris v grapi Volarje. Foto: I. Dakskobler

from the Volarja grouped mainly with the relevés from the Brezna Grapa gorge at Grahovo ob Bači and the nearby Mrzlica (subassociation -hymenostylietosum recurvirostri), while the relevés from the first and third locality grouped with the relevés of the subassociation -cratoneuretosum commutati.

Table 1 comprises new, previously unpublished relevés (12) as well as some already published relevés that show the greatest similarity to the new relevés. Based on the previously described comparison they are classified into the association Eucladio-Adiantetum Br.-Bl. 1931. Its subassociation -hymenostylietosum recurvirostri Dakskobler, Martinčič et Rojšek 2014 comprises the relevés from the Brezna/Brizna Grapa gorge at Grahovo ob Bači and the Mrzlica (which is the closest to the new locality in the nearby Volarja) as well as one releve from the Sopet brook at Plave and four relevés from the Volarja gorge. The latter grouped separately and based on their species composition they can be classified into the new variant with Pinguicula alpina. Its differential species include Calamagrostis varia (mainly on account of higher coverage that it has here compared to the relevés of other syntaxa compared), Carex brachystachys, Campanula cespitosa and Saxifraga aizoides. The last three species have not yet been recorded on other maidenhair fern localities in Slovenia. While T. Wraber reported Campanula cespitosa for the maidenhair fern locality at Grahovo ob Bači (field notes from 1984, Wraber's library at the Botanical Garden of the University of Ljubljana), he gave no mention of this species for this locality in the published article (WRABER 1986). Individual occurrences of these taxa, which are mainly distributed in the Alps, characterise the stands of the new variant both in terms of phytogeography and ecology. Such occurrence can be attributed to the proximity of mountains rising to $2,000 \mathrm{~m}$ and higher under which these gorges with their headwaters are situated as well as with special geological and geomorphological conditions and the local climate. An even more prominent example of cooccurrence of Mediterranean fern and hygrophilous subalpine-alpine chasmophytic species, grassland and headwaters species is known from Italy, where a new association Himenostylio recurvirostri-Pinguiculetum 


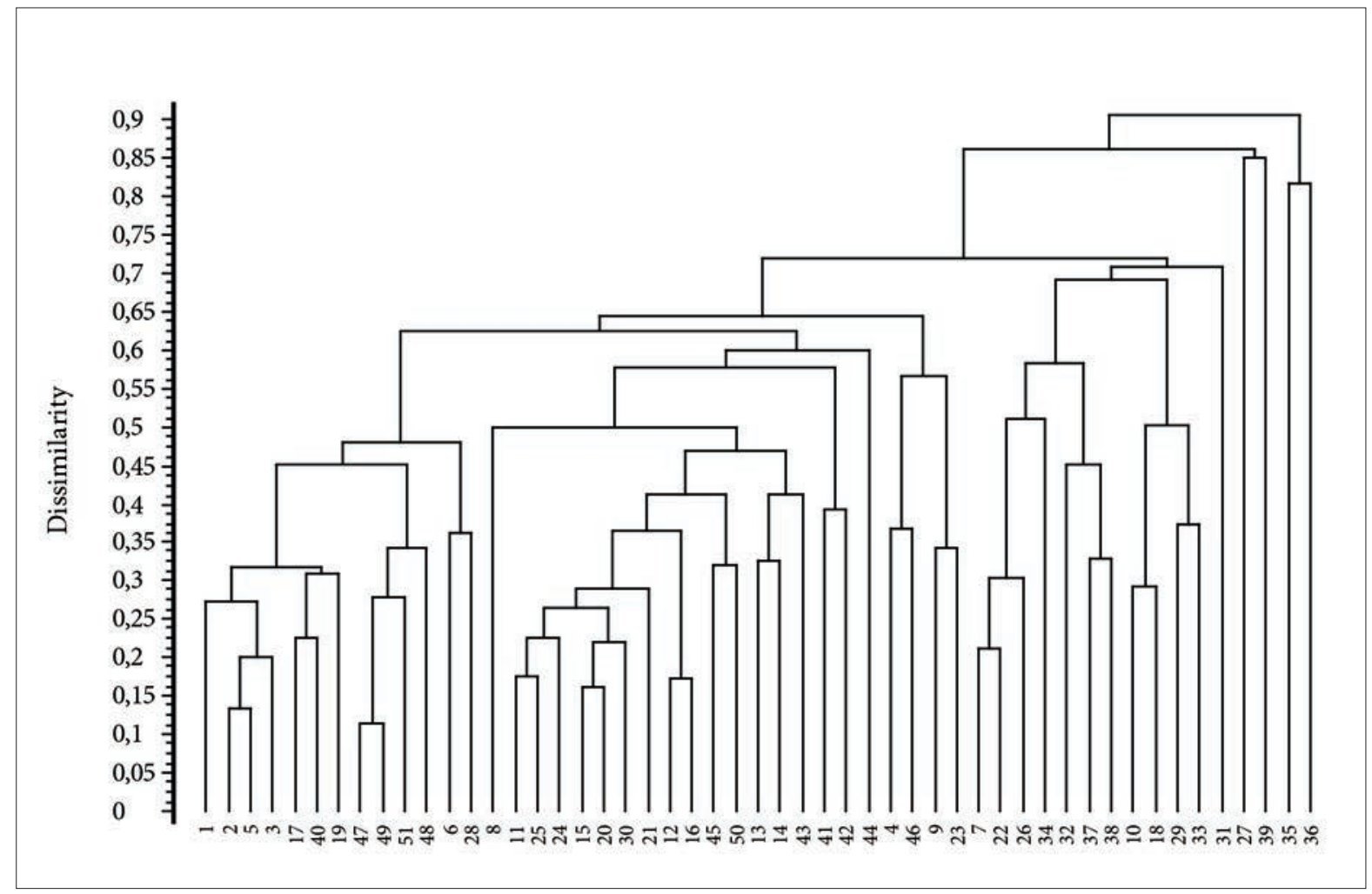

Figure 6: Dendrogram of relevés of communities with dominant Adiantum capillus-veneris in Slovenia (UPGMA, 1-similarity ratio). Stands of the subassociation Eucladio-Adiantetum hymenostylietosum recurvirostri are on the left side of the dendrogram, stands of the syntaxa Eucladio-Adiantetum cratoneuretosum commutati, -eucladietosum and Adianto-Molinietum are in the central part and stands of the syntaxa Eucladio-Adiantetum conocepahaletosum conici and Phyteumato columnae-Adiantetum on the right.

Slika 6: Dendrogram popisov združb z vrsto Adiantum capillus-veneris v Sloveniji (UPGMA, komplement Wishartovega koeficienta podobnosti ). V levem delu dendrograma so sestoji subasociacije Eucladio-Adiantetum hymenostylietosum recurvirostri, $v$ srednjem delu sestoji sintaksonov Eucladio-Adiantetum cratoneuretosum commutati, -eucladietosum in AdiantoMolinietum, v desnem delu pa sestoji sintaksonov Eucladio-Adiantetum conocepahaletosum conici in Phyteumato columnaeAdiantetum

poldinii (Giovagnoli \& Tasinazzo 2012) with Pinguicula alpina and Carex brachystachys was described several years ago in the ravines of the Venetian Prealps.

Two relevés from the Volarja gorge at Selišče and the Sopet at Plave as well as the relevé from Istria (Piševec) show greater similarity with the relevés classified into the subassociation Eucladio-Adiantetum cratoneuretosum commutati (Pritivera \& Lo Guidice) Deil 1996.

Four relevés stand out in Table 1, namely those that grouped separately also in the comparison of all relevés from Slovenia (relevés 44, 4, 46 and 9 in Figure 6 or relevés 20 to 23 in Table 1). They are classified into the new association Adianto capilli-veneris-Molinietum arundinaceae ass. nov. that was provisionally described already in 2014. For now it is known on four very different localities situated far apart from each other in the Alpine, pre-Alpine-sub-Mediterranean and sub-Mediterranean phytogeographical regions. The largest area that its stands occupy is in the gorge of the Volarja (Figure 7) and based also on these large surface areas it can be typified as new. Its nomenclature type, holotypus, is relevé 21 in Table 1 . The stands of the new association are characterised by two herb layers. The upper, which is very distinct and conspicuous, is dominated by Molinia caerulea subsp. arundinacea (M. arundinacea), and the lower, which is less conspicuous and recognisable only close up, is dominated by Adiantum capillus-veneris. The Central-European nomenclature requires communities to be named after the dominating species of the highest stand layer, so the rank of the subassociation Eucladio-Adiantetum molinietosum arundinaceae would be less appropriate for these stands. Nevertheless, because of maidenhair 


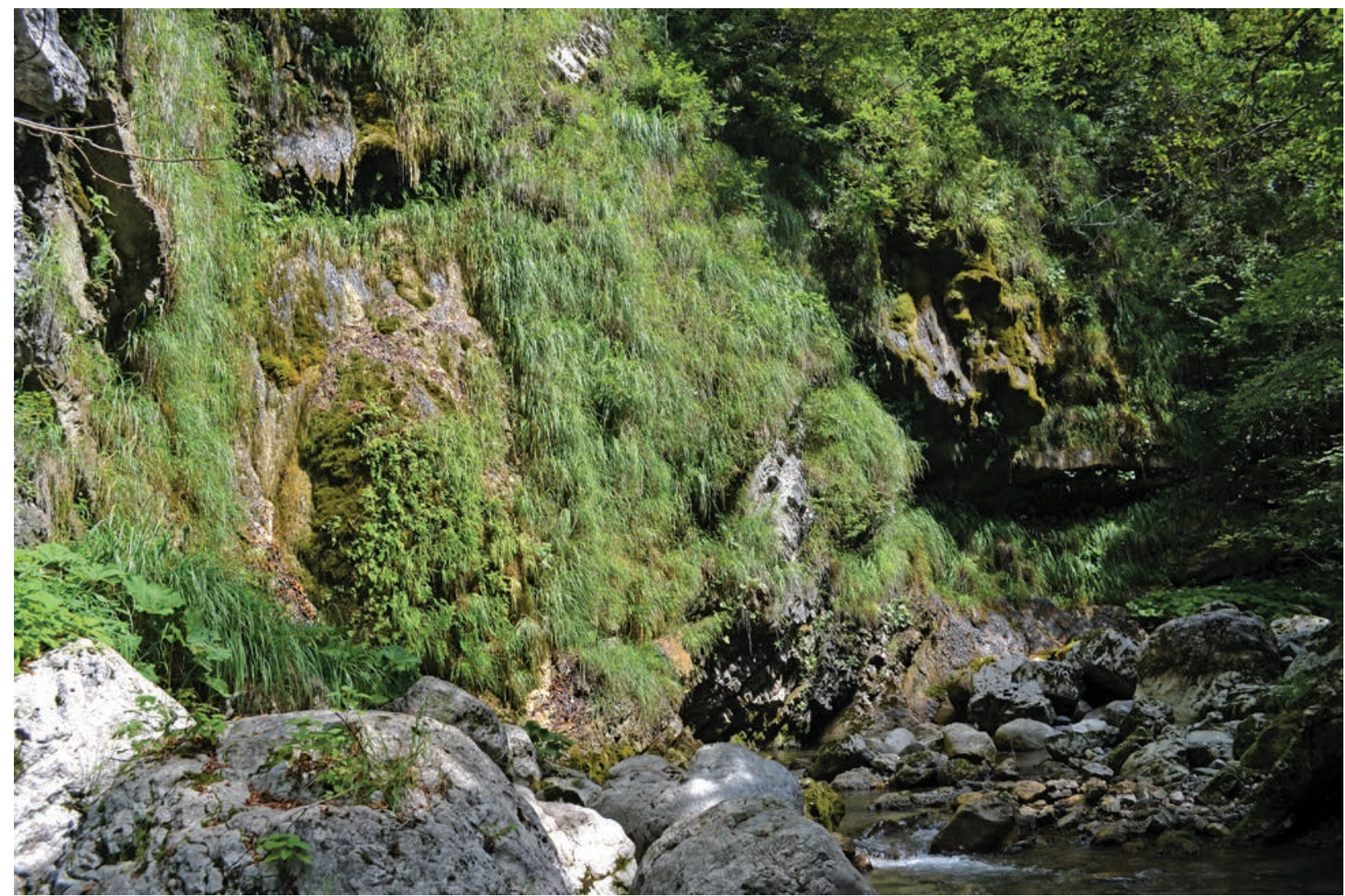

Figure 7: Stands of the syntaxa Eucladio-Adiantetum hymenostylietosum recurvirostri (the smaller area in the left part of the figure) and Adianto-Molinietum arundinaceae (the bigger area in the central part of the figure) in the gorge of the Volarja. Photo: I. Dakskobler

Slika 7: Sestoja sintaksonov Eucladio-Adiantetum hymenostylietosum recurvirostri (manjša površina bolj v levem delu slike) in Adianto-Molinietum arundinaceae (večja površina v srednjem delu slike) v grapi Volarje. Foto: I. Dakskobler

fern and diagnostic moss species (Eucladium verticillatum, Hymenostylium recurvirostre, Palustriella commutata) the new association is classified into the alliance Adiantion capilli-veneris Br.-Bl. ex Horvatić 1934, order Adiantetalia capilli-veneris Br.-Bl. ex Horvatić 1934 and class Adiantetea capilli-veneris Br.-Bl. 1948.
Its stands on steep to very steep slopes with dolomite, limestone or flysch bedrock, where tufa is frequently deposited from, characterise a long-term successional stage in the gradual overgrowing of these extreme sites with shrub vegetation, in the case of the Volarja on the edges of the slope break.

\section{CONCLUSIONS}

On three locations in the gorge of the Volarja/Volarnik at Selišče (Krn Mountains, Julian Alps) we came across a rare and protected fern Adiantum capillus-veneris. Compared to the only known locality in the basin of the Volarja brook (in the Mrzlica gorge), the second new locality along the brook is very large (extending over several ares) and the richest in the number of specimens in the entire Soča Valley. In terms of the species composition the maidenhair communities there are similar to the communities on other localities known so far in the Julian Alps and in the Central Soča Valley. Two relevés are classified into the subassociation Eucladio-Adiantetum cratoneuretosum commutati and four into the new variant of the subassociation $\mathrm{Eu}$ cladio-Adiantetum hymenostylietosum recurvirostri, var. Pinguicula alpina. This montane headwaters species has been reported for maidenhair fern localities in the Alpine foothills of northeastern Italy, whereas in 
Slovenia the Volarja is the only place where these two species occur together. One of the differential species of the new variant is also Saxifraga aizoides, a montane-alpine species of moist screes and headwaters, one of whose lowest localities in Slovenia is along the Volarja, at the elevation of only $230 \mathrm{~m}$.

Maidenhair ferns along the Volarja occur on a very large area also in a community with tall moor grass (Molinia caerulea subsp. arundinaceae) and such stands, known on smaller areas also elsewhere in western and southwestern Slovenia, were classified into the new association Adianto capilli-veneris-Molinietum arundinaceae.
The diverse basin of the Volarja/Volarnik under Mt. Krn with its numerous waterfalls and other fascinating geomorphological and geological phenomena (PoDobNik 1983, RojšEk 1991) have been declared a natural monument and part of the Natura 2000 site named Soča with the Volarja. The new maidenhair fern localities are not endangered yet as they are not easily accessible, although they are in the vicinity of a popular path leading to the waterfalls. There are no other significant human interventions in these localities, but their populations nevertheless require careful monitoring in the future.

\section{POVZETEK}

V grapi Volarje/Volarnika pri Seliščih (Krnsko pogorje, Julijske Alpe) smo na treh krajih našli redko in zavarovano praprotnico Adiantum capillus-veneris. V primerjavi $\mathrm{z}$ do zdaj znanim edinim nahajališčem $\mathrm{v}$ porečju tega potoka (v soteski Mrzilce), je drugo novo nahajališče ob Volarji zelo obsežno (na površini več arov) in po številu primerkov najbogatejše $\mathrm{v}$ celotnem Posočju. Po vrstni sestavi so združbe venerinih laskov na njem podobne združbam na drugih do zdaj znanih nahajališčih v Julijskih Alpah in v Srednjem Posočju. Dva popisa uvrščamo v subasociacijo Eucladio-Adiantetum cratoneuretosum commutati, štiri pa v novo varianto Eucladio-Adiantetum hymenostylietosum recurvirostri var. Pinguicula alpina. To gorsko vrsto povirij že poznajo na nahajališčih venerinih laskov v alpskem prigorju severovzhodne Italije, v Sloveniji pa je Volarja za zdaj edini kraj, kjer rasteta skupaj. Ena izmed razlikovalnic nove variante je tudi (visoko)gorska vrsta vlažnih melišč in povirij Saxifraga aizoides, ki ima ob Vo- larji na nadmorski višini le $230 \mathrm{~m}$ eno izmed svojih najnižje ležečih nahajališč v Sloveniji.

Ob Volarji venerini laski na precej veliki površini rastejo tudi v združbi s trstikasto stožko (Molinia caerulea subsp. arundinaceae) in take sestoje, ki jih na manjših površinah poznamo tudi drugod $\mathrm{v}$ zahodni in jugozahodni Sloveniji, smo uvrstili v novo asociacijo Adianto capilli-veneris-Molinietum arundinaceae.

Razgibano porečje Volarje/Volarnika pod Krnom je zaradi številnih slapov in drugih zanimivih geomorfoloških in geoloških pojavov (PoDOBNik 1983, RoJšEK 1991) razglašeno za naravni spomenik in sodi tudi $v$ območje Natura 2000 z imenom Soča z Volarjo. Nova nahajališča venerinih laskov za zdaj še niso ogrožena, saj so razmeroma težko dostopna, vendar poteka blizu precej obiskana pot $\mathrm{k}$ slapovom. Drugih človekovih posegov na nahajališčih ni zaznati. Kljub vsemu bo v prihodnje potrebno pozorno spremljati njihove populacije.

\section{ACKNOWLEDGEMENTS}

We would like to thank the heirs of the late Tone Wraber for giving his manuscripts and professional literature to the safekeeping of the Botanical Garden of the University of Ljubljana, and to its director, Dr. Jože Bavcon, who allowed us to examine professor's legacy. Dr. Špela Goričan helped us to translate some of the geological terms into English and Iztok Sajko prepared Figure 2 for print. The authors acknowledge the financial support from the Slovenian Research Agency (research core funding No. P1-0236). English translation by Andreja Šalamon Verbič. 


\section{REFERENCES - LITERATURA}

Aeschimann, D., K. Lauber, D. M. Moser \& J.-P. Theurillat, 2004: Flora alpina. Bd. 1: Lycopodiaceae-Apiaceae. Haupt Verlag, Bern, Stuttgart, Wien.

Braun-Blanquet, J., 1964: Pflanzensoziologie. Grundzüge der Vegetationskunde. 3. Auflage. Springer, Wien New York.

Buser, S., 1986: Tolmač listov Tolmin in Videm (Udine) L 33-64 L 33-63. Osnovna geološka karta 1:100 000. Beograd. BUSER, S., 1987: Osnovna geološka karta SFRJ. Tolmin in Videm 1:100 000. Zvezni geološki zavod, Beograd.

Buser, S., 2009: Geološka karta Slovenije 1: 250.000. Geological map of Slovenia 1.250,000. Geološki zavod Slovenije, Ljubljana.

Cegnar T., 1998: Temperatura zraka. In: J. Fridl, D. Kladnik, M., Orožen Adamič \& D. Perko (eds.): Geografski atlas Slovenije. Država v prostoru in času. Državna založba Slovenije, Ljubljana, pp. 100-101.

Dakskobler, I., 2017: Dve botanični opombi pod črto: plazeča sretena (Geum reptans) pod Triglavom in venerini laski (Adiantum capillus-veneris) v grapi Volarje pri Seliščih. Proteus 79 (5): 216-223.

Dakskobler, I., A. Martinčıč, D. RojšEk, 2014: Phytosociological analysis of communities with Adiantum capillus-veneris in the foothills of the Julian Alps (Western Slovenia). Hacquetia (Ljubljana) 13 (2): 235-258. https:// doi.org/10.2478/hacq-2014-0016

Giovagnoli, L. \& S. Tasinazzo, 2012: Hymenostylio recurvirostri-Pinguiculetum poldinii ass. nova in the Valbrenta ravines (Venetian Prealps): a new palaeoendemic plant association belonging to the class Adiantetea Br.-Bl. 1948. Plant Sociology 29 (2): 49-58. https://doi.org/10.7338/pls2012492/03

MAAREL, van der E., 1979: Transformation of cover-abundance values in phytosociology and its effects on community similarity. Vegetatio 39 (2): 97-114. https://doi.org/10.1007/BF00052021

Martinčič, A., T. Wraber, N. Jogan, A. Podobnik, B. Turk, B. Vreš, V. Ravnik, B. Frajman, S. Strgulc Krajšek, B. TrČak, T. Bačič, M. A. Fischer, K. Eler \& B. Surina, 2007: Mala flora Slovenije. Ključ za določanje praprotnic in semenk. Četrta, dopolnjena in spremenjena izdaja. Tehniška založba Slovenije, Ljubljana.

Medveščex, P. \& D. SKRT, 2016: Staroverstvo in straroverci. Katalog etnološke zbirke Pavla Medveščka 2. Goriški muzej, Nova Gorica.

Mekinda-Majaron,T., 1995: Klimatografija Slovenije. Temperatura zraka 1961-1990. Hidrometeorološki zavod Republike Slovenije, Ljubljana.

PodAnI, J., 2001: SYN-TAX 2000. Computer Programs for Data Analysis in Ecology and Systematics. User's Manual, Budapest.

Podobnik, R., 1983: Slapovi v okolici Vrsna in Krna. In: A. Ramovš: Slapovi v Sloveniji. Slovenska matica, Ljubljana, pp. 110-118.

RojšEK, D., 1991: Naravne znamenitosti Posočja. Državna založba Slovenije, Ljubljana.

RojšEk, D., 2015a: Venerini laski (Adiantum capillus-veneris L.) v Posočju. Prvi del. Proteus (Ljubljana) 77 (9-10): 399-408.

RojšEk, D., 2015b: Venerini laski (Adiantum capillus-veneris L.) v Posočju. Drugi del. Proteus (Ljubljana) 78 (1): 24-34.

Ros, R. M., V. Mazimpaka, U. Abou-Salama, M. Aleffi, T. L. Blockeel, M. Brugués, M. J. Cano, R. M. Cros, M. G. Dia, G. M. Dirkse, W. El Saadawi, A. Erda Ğ, A. Ganeva, J. M. González-Mancebo, I. Hernstadt, K. Khalil, H. Kürschner, E. Lanfranco, A. Losada-Lima, M. S. Refai, S. Rodríguez-Nunez, M. Sabovljević, C, Sérgio, H. Shabbara, M. Sim-Sim \& M. Söderström, 2007: Hepatics and Anthocerotes of the Mediterranean, an annotated checklist. Cryptogamie, Bryologie 28 (4): 351-437.

Ros, R. M., V. Mazimpaka, U. Abou-Salama, M. Aleffi, T. L. Blockeel, M. Brugués, R. M. Cros, M. G. Dia, G. M. Dirkse, I. Draper, W. El SaAdawi, A. ErdaĞ, A. Ganeva, R. Gabriel, J. M. González-Mancebo, I. Hernstadt, V. Hugonnot, K. Khalil, H. Kürschner, A. Losada-Lima, L. Luís, S. Mifsud, M., Privitera, M. Puglisi, M. Sabovljević, C. Sérgio, H. M. Shabbara, M. Sim-Sim, A. Sotiaux, R. Tacchi, A. VanderPOORTEN \& O. Werner, 2013: Mosses of the Mediterranean, an annotated checklist. Cryptogamie, Bryologie 34 (2): 99-283.

SelišKar, T., B. Vreš \& A. SelišKar, 2003: FloVegSi 2.0. Fauna, Flora, Vegetation and Paleovegetation of Slovenia. Computer programme for arranging and analysis of biological data. Biološki inštitut ZRC SAZU, Ljubljana.

ŠILC, U. \& A. ČARNI, 2012: Conspectus of vegetation syntaxa in Slovenia. Hacquetia (Ljubljana) 11 (1): 113-164. https://doi.org/10.2478/v10028-012-0006-1 
Theurillat, J.-P., 2004: Pflanzensoziologisches System. In: D. Aeschimann, K. Lauber, D. M. Moser \& J-P. Theurillat: Flora alpina 3: Register. Haupt Verlag, Bern, Stuttgart, Wien, pp. 301-313.

Wraber, T., 1986: Vsega po nekaj o venerinih laskih. Proteus (Ljubljana) 48 (7): 259-263.

Zupančıč, B., 1995: Klimatografija Slovenije. Padavine 1961-1990. Hidrometeorološki zavod Republike Slovenije, Ljubljana.

Zupančič, B., 1998: Padavine. In: J. Fridl, D. Kladnik, M. Orožen Adamič \& D. Perko (eds.): Geografski atlas Slovenije. Država v prostoru in času. Državna založba Slovenije, Ljubljana, pp. 98-99. 


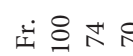

$\ddot{2} \approx \simeq \simeq 0$

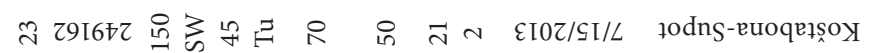

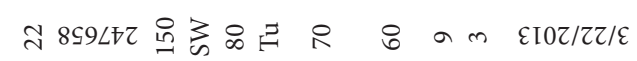

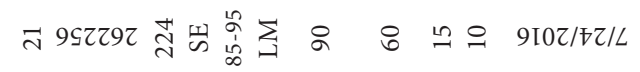

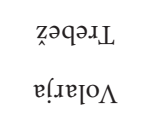

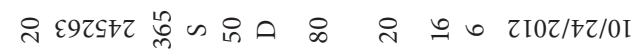

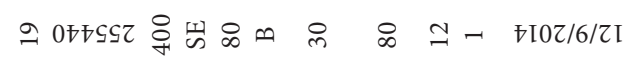

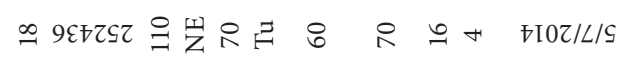

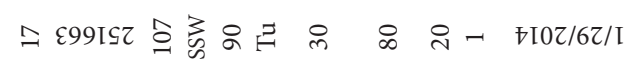

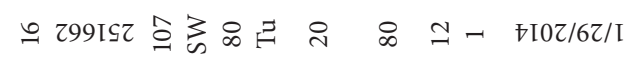

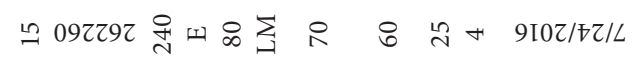

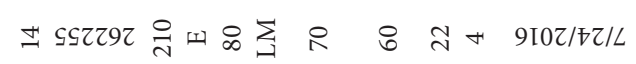

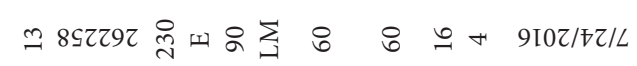

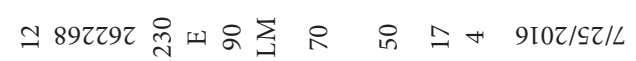

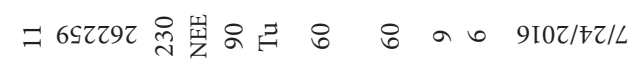

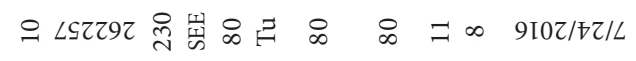

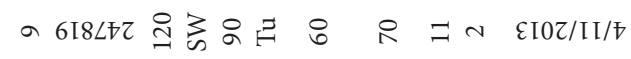

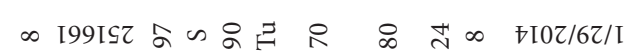

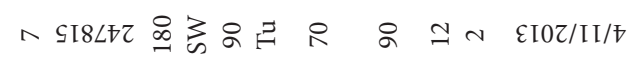

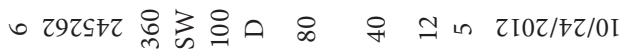

n tazstr

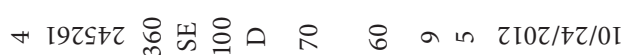

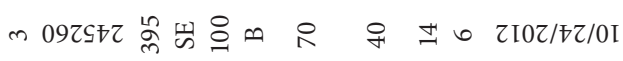

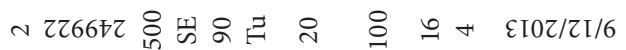

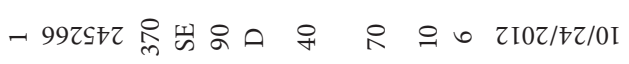

$$
\text { 푀 위 로 }
$$
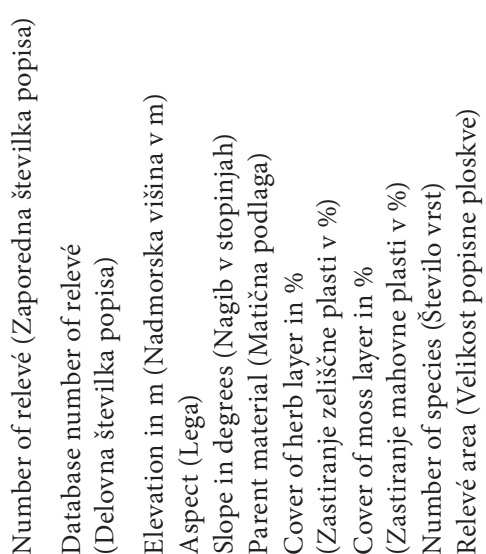

edexo̊ euzəxg

edexo euzə.x

ววนวร્ก!

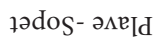

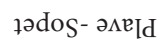

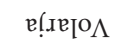

еำто $\Lambda$

еำто $\Lambda$

еำ

еา.лето $\Lambda$

$$
\text { e!..xए }[0 \Lambda
$$

eq! $\mathrm{*}$-(u!)

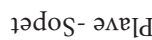

วग्र $\Lambda \mathrm{V}$

edexo̊ euzวrg

edexo̊ euzəxg

еdexo euzaxg

edexo̊ euzวtg

edexo euzəxg eว!]zxh
I/8†S0

Z/Lt66

†/LゅL6

I/6786

I/6ฑ86

I/8† $\subseteq 0$

†/L†66

†/L†66

$\varpi / \angle \oplus \angle 6$

†/L†L6

$\varpi / \angle \oplus \angle 6$

$\varpi / \angle \nsucc \angle 6$

$\varpi / \angle \oplus L 6$

$\varpi / \angle \oplus \angle 6$

†/L†86

†/Lt66

I/8†66

I/6786

I/6†86

I/6†86

I/6†86

$\varepsilon / 87 \angle 6$

I/6Ð86

ב⿺辶.
STIZ0T

$\varepsilon 0 \angle I 6 \varepsilon$

97996ع

OLLZIT

I ILZIT

$\angle \angle 966 \mathcal{E}$

$\angle \mathcal{E} \angle 06 \mathcal{E}$

$6 Z \angle 06 \varepsilon$

ऽৎ996E

$62996 \mathcal{E}$

$67996 \mathcal{E}$

Eт996E

$62996 \varepsilon$

乙E996\&

$90896 \mathcal{E}$

ZLL06E

$88 \subseteq 86 \varepsilon$

๓9LZIt

89L2IT

†9LZIT

tILZIT

๑99L6E

9SLZIT

$$
\text { घ }
$$

I668\&0S

0SEZ0IS

t820ZIS

09SEIIS

ZLSEIIS

ZIZ6E0S

SST00IS

87t00IS

†8E0ZIS

StIOZIS

๓9Z0ZIS

98Z0ZIS

†SZ0ZIS

ILZOZIS

96LLOIS

89700IS

††690IS

ZSSEIIS

99SEIIS

Z†SEIIS

ZLSEIIS

98L0ZIS $9 \mathcal{G S E I S S}$

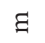

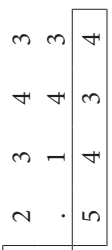

$N-$.

$+n$
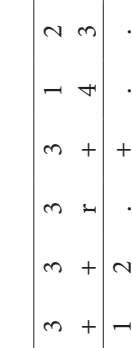

:
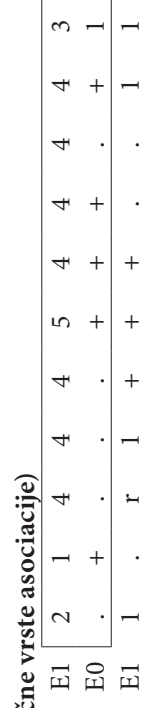

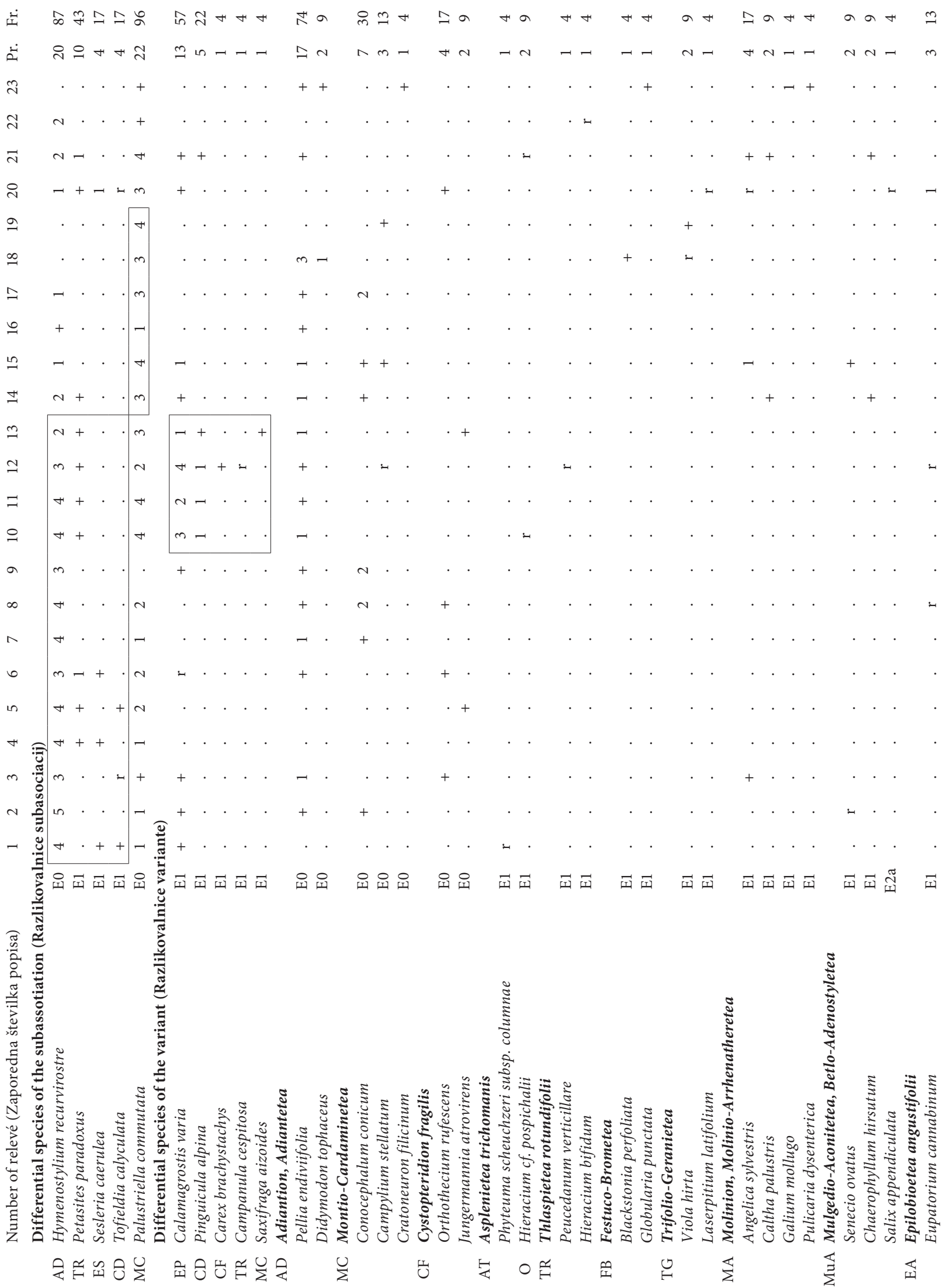

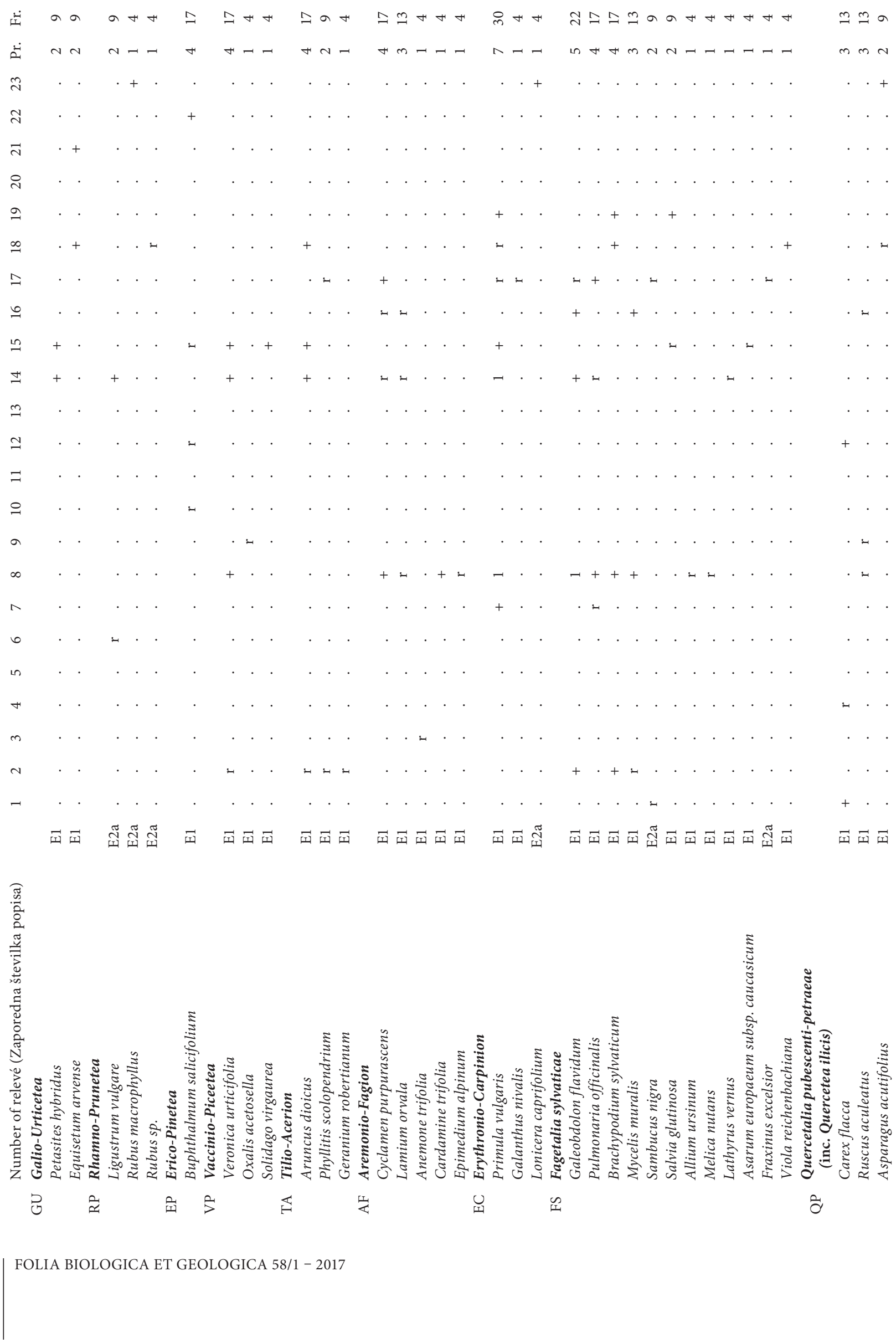


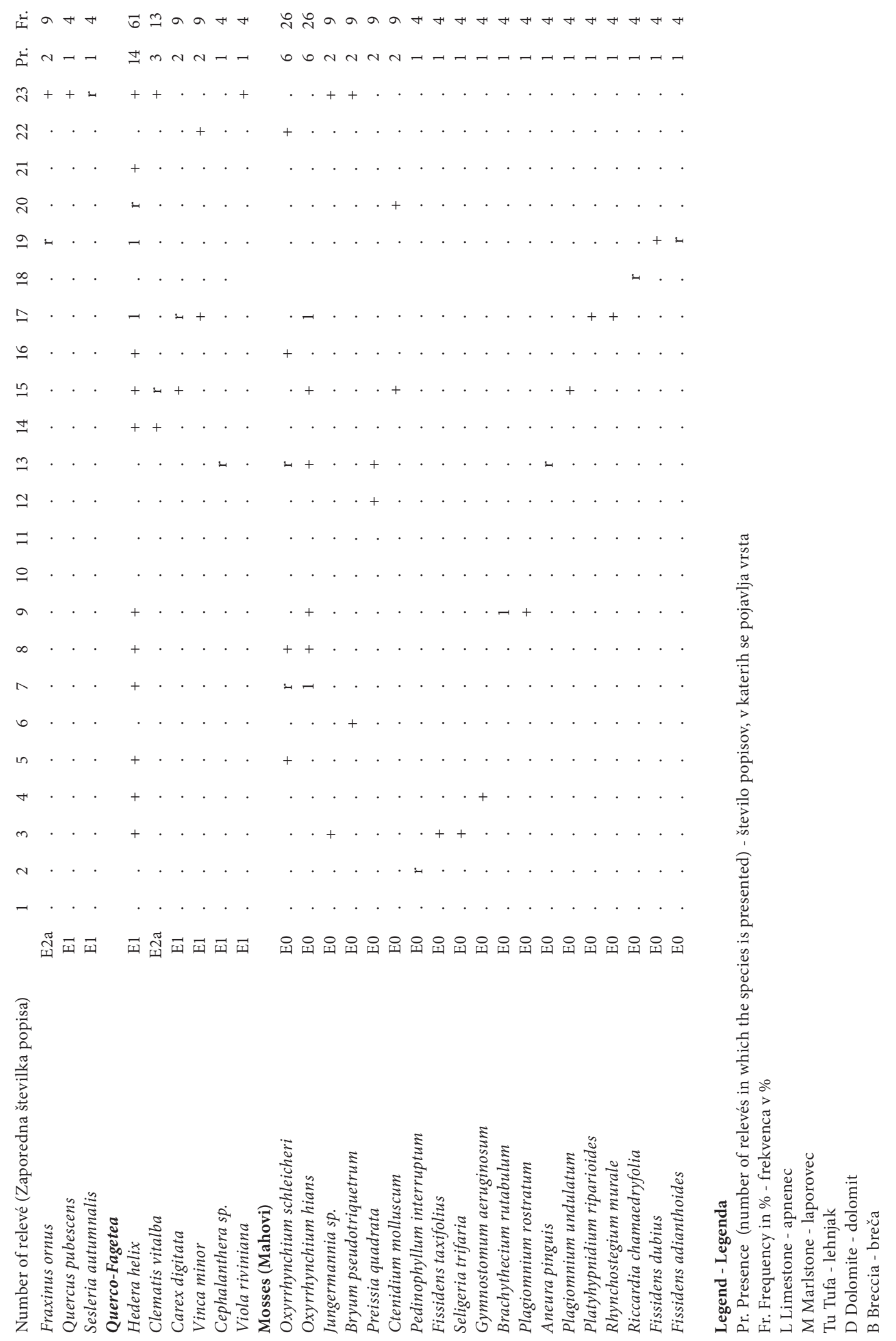

岩

$\Sigma$ 
